\title{
GLOSA DO WYROKU NACZELNEGO SĄDU ADMINISTRACYJNEGO Z DNIA 16 GRUDNIA 2014 R., SYGN. II OSK 2957/12
}

\section{COMMENT ON THE JUDGEMENT OF THE SUPREME ADMINISTRATIVE COURT OF 16 DECEMBER 2014, II OSK 2957/12}

\section{STRESZCZENIE}

Przedmiotem glosy jest analiza art. 127 ust. 7a ustawy Prawo wodne w związku z art. 49 kodeksu postępowania administracyjnego, w kontekście obowiązku ustalenia kręgu stron postępowania w sprawie wydania pozwolenia wodnoprawnego przez organ prowadzący to postępowanie. W ocenie sądu administracyjnego odesłanie zawarte

Doktor nauk prawnych, adiunkt w Katedrze Prawa Ochrony Środowiska Wydziału Prawa i Administracji Uniwersytetu Mikołaja Kopernika. 
w art. 127 ust. 7a u.p.w. (wcześniej art. 127 ust. 9 u.p.w.) do art. 49 k.p.a. zwalnia organ administracyjny z obowiązku ścisłego ustalenia kręgu stron postępowania. Stanowisko przyjęte przez Naczelny Sąd Administracyjny należy ocenić krytycznie jako obarczone błędem logicznym, a w konsekwencji prowadzące do zaprzeczenia istocie jurysdykcyjnego postępowania administracyjnego, będącego postępowaniem w indywidualnej sprawie administracyjnej, to jest w sprawie o ściśle określonym zakresie podmiotowym.

\section{Słowa kluczowe}

Postępowanie administracyjne; strona; doręczenia; prawo wodne.

\section{ABSTRACT}

The subject of the commentary is to analyse article 127 item $7 \mathrm{a}$ of the Water Law in connection with article 49 of the Administrative Proceedings Code (APC) in the context of the obligation to establish the circle of parties to the procedure to issue a water permit by the authority conducting this procedure. In the opinion of the administrative court, the reference contained in article 127 item 7a of the Water Law (previously article 127 item 9 Water Law) to article 49 APC releases the administrative authority from the obligation to strictly determine the circle of parties. The stand taken by the Supreme Administrative Court should be evaluated critically, as logically flawed, and consequently leading to the denial of the essence of jurisdictional administrative proceedings, which are proceedings in an individual administrative case, i.e. in a strictly personally defined scope.

\section{Keywords}

Administrative proceedings; party; delivery; water law. 


\section{GLOSA}

Przedmiotem glosowanego orzeczenia była ocena prawidłowości ustalenia, przez organ prowadzący postępowanie administracyjne, kręgu stron postępowania w sprawie wydania pozwolenia wodnoprawnego, w związku z zastosowaniem w postępowaniu administracyjnym art. 49 k.p.a. ${ }^{1}$, upoważniającego do dokonywania doręczeń pism procesowych, w trybie obwieszczenia. Istotą spornego zagadnienia była kwestia, czy upoważnienie organu do zastosowania art. 49 k.p.a., zwalnia ten organ z obowiązku ustalenia kręgu stron postępowania, a w szczególności, czy przyjęcie przez organ, iż stroną postępowania, a w konsekwencji - decyzji, są osoby zmarłe, skutkuje wadliwością podjętego rozstrzygnięcia.

Przedmiotem skargi kasacyjnej inicjującej rozstrzygnięcie NSA był wyrok WSA w Krakowie ${ }^{2}$, którym sąd ten uchylił decyzję Dyrektora Regionalnego Zarządu Gospodarki Wodnej w Krakowie, uchylającą decyzję Starosty Żywieckiego w przedmiocie pozwolenia wodnoprawnego na pobór wód podziemnych oraz na wykonanie urządzeń służących do poboru wód. Dyrektor Regionalnego Zarządu Gospodarki Wodnej w podstawie swojej decyzji wskazał, iż z akt prowadzonego postępowania wynika, iż organ I instancji uznał za strony postępowania osoby nieżyjące, kierując do nich wydawane $\mathrm{w}$ toku postępowania pisma procesowe, w tym decyzję administracyjną. W ocenie organu odwoławczego stan ten skutkuje stwierdzeniem, iż decyzja organu administracyjnego obarczona jest wadą prawną (art. 156 $\S 1$ pkt 2 k.p.a.) i jako taka podlega weryfikacji instancyjnej. Wojewódzki Sąd Administracyjny, rozpoznając skargę na decy-

1 Ustawa z dnia 14 czerwca 1960 r. Kodeks postępowania administracyjnego, tekst jedn. Dz.U. z 2013 r., poz. 267 ze zm., (dalej: kodeks postępowania administracyjnego lub k.p.a.).

2 Wyrok WSA w Krakowie z dnia 12 marca 2013 r., II Sa/Kr 1739/11, CBOSA. 
zję Dyrektora Regionalnego Zarządu Gospodarki Wodnej, zakwestionował stanowisko tegoż organu wskazując, iż w przypadku upoważnienia organu do dokonania doręczenia w drodze obwieszczenia (art. 49 k.p.a. w związku z art. 127 ust. 7 ustawy Prawo wodne ${ }^{3}$ ), organ administracyjny nie ma obowiązku ścisłego ustalenia kręgu stron postępowania administracyjnego, w szczególności ustalenia następców prawnych właścicieli nieruchomości położonych w zasięgu oddziaływania zamierzonego korzystania z wód lub planowanych do wykonania urządzeń wodnych. W tym stanie WSA uznał, iż wydanie decyzji kasacyjnej przez organ odwoławczy było nieuzasadnione.

Rozpatrując skargę kasacyjną Dyrektora Regionalnego Zarządu Gospodarki Wodnej od wyroku WSA, NSA uznał, co do zasady, rozstrzygnięcie WSA za prawidłowe. Sąd kasacyjny przyjął, iz - zgodnie z art. 127 ust. $9^{4}$ u.p.w. - w sytuacji, gdy liczba stron postępowania wodnoprawnego przekracza 20, to do stron innych niż wnioskodawca, dyrektor regionalnego zarządu gospodarki wodnej, właściciel wody i właściciel urządzeń wodnych stosuje się przepis art. 49 k.p.a. W ocenie sądu uzasadnieniem dla przyjętych, na poziomie ustawy Prawo wodne, rozwiązań jest uwzględnienie przez ustawodawcę możliwości wystąpienia $\mathrm{w}$ postępowaniu dużej ilości potencjalnych stron i odstąpienie w związku z tym od "normalnego trybu doręczania pism na rzecz ogłoszenia publicznego”. Zdaniem sądu rozumowanie niweczące cel wprowadzenia regulacji szczególnej jest nieuzasadnione: „gdyby organ musiał ustalać krąg stron postępowania, to nie byłoby potrzeby wprowadzania szczególnego trybu informowania stron o decyzjach i innych czynnościach postępowania". W swych dalszych wywodach NSA wskazuje, iż or-

3 Ustawa z dnia 18 lipca 2011 r. Prawo wodne, tekst jedn. Dz.U. z 2015 r., poz. 469 ze zm., (dalej: ustawa Prawo wodne lub u.p.w.).

4 W dacie wszczęcia postępowania administracyjnego, w wyniku którego wydana została decyzja administracyjna poddana kontroli sadów administracyjnych, obowiązywał art. 127 ust. 7 i 9 ustawy Prawo wodne w brzmieniu przed dniem wejścia w życie ustawy z dnia 5 stycznia 2011 r. o zmianie ustawy Prawo wodne oraz niektórych ustaw (Dz.U. Nr 32, poz. 159). Po wskazanej nowelizacji odpowiednikiem art. 127 ust. 9 u.p.w. sprzed nowelizacji jest art. 127 ust. 7a u.p.w. 
gan administracji ma podstawy do zastosowania art. 49 k.p.a. wówczas, gdy przepis tak stanowi, nie ma zaś podstaw, aby z treści tego przepisu wyprowadzić wniosek, że „uprzednio należy ustalić zamknięty wykaz wszystkich stron mogących posiadać interes prawny do udziału w postępowaniu". W ocenie sądu obwieszczenie, o którym stanowi art. 49 k.p.a., ma ten skutek, że każdy zainteresowany kto uważa się za stronę postępowania, może dowiedzieć się o toczącym się postępowaniu i jego przebiegu, co umożliwia ewentualny czynny w nim udział. W związku z tym do podmiotów zainteresowanych tym postępowaniem, a nie do organu prowadzącego postępowanie, należy podjęcie czynności zapewniających im czynne uczestnictwo w postępowaniu administracyjnym. Ponadto, w ocenie sądu, upoważnienie do dokonywania doręczeń w trybie art. 49 k.p.a, z powodu wprowadzenia daleko idących odstępstw od zasady oficjalności doręczeń, istotnie ogranicza stosowanie zasad ogólnych k.p.a. w postaci zasady informowania (art. 9 k.p.a.) i zasady czynnego udziału stron w postępowaniu (art. $10 \S 1$ k.p.a.), wprowadzając „swoistą gradację poszczególnych kategorii stron postępowania (których katalog ustalany jest na zasadach ogólnych, tj. stosownie do treści art. 28 k.p.a. - zob. art. 127 ust. 7 i ust. 9 ustawy Prawo wodne). Z kolei najdalej idące uprawnienia przysługują wnioskodawcy, właścicielowi wody, właścicielowi urządzeń wodnych i regionalnemu dyrektorowi zarządu gospodarki wodnej, którym w normalnym trybie doręcza się dalej odpis decyzji jak i oczywiście pisma procesowe, w odróżnieniu od innych zainteresowanych podmiotów zawiadamianych tylko $\mathrm{w}$ trybie art. 49 k.p.a.”.

II.

Zajęte przez Naczelny Sąd Administracyjny stanowisko należy ocenić krytycznie jako obarczone błędem logicznym, a w konsekwencji prowadzące do zaprzeczenia istocie jurysdykcyjnego postępowania administracyjnego, będącego postępowaniem $\mathrm{w}$ indywidualnej sprawie administracyjnej, to jest w sprawie o ściśle określonym zakresie podmiotowym. Z istoty postępowania administracyjnego wynika, iż jego celem jest 
wydanie decyzji administracyjnej konkretyzującej prawa i obowiązki stron tego postępowania ${ }^{5}$. Decyzja ta, będąc aktem skierowanym do imiennie określonego adresata, ustala, tworzy lub znosi prawa lub obowiązki tego adresata. Oznacza to, że organ wydając decyzję administracyjną w określonej sprawie indywidualnej, ustala konsekwencje prawne stanu faktycznego, a tym samym kształtuje albo stwierdza pozycję prawną podmiotu będącego stroną postępowania administracyjnego ${ }^{6}$.

Pojęcie strony jest węzłowym pojęciem postępowania administracyjnego ${ }^{7}$, będąc jednocześnie jednym z najbardziej kontrowersyjnych pojęć $\mathrm{w}$ nauce prawa administracyjnego ${ }^{8}$. $\mathrm{W}$ ujęciu terminologicznym jest to pojęcie proceduralne, charakteryzujące określonych uczestników postępowania administracyjnego i odnoszące się wyłącznie do sytuacji zdeterminowanej postępowaniem administracyjnym (strona nie występuje poza postępowaniem administracyjnym $)^{9}$. Jednocześnie w doktrynie prawa administracyjnego wskazuje się, iż strona postępowania administracyjnego jest instytucją procesową, rozumianą jako zespół norm prawnych odnoszących się do sytuacji prawnej wyodrębnionej ze względu na jej doniosłość społeczną lub/i prawną, a w zespole tych norm mieszczą się zarówno normy prawa materialnego (administracyjnego, cywilnego, finansowego, ubezpieczeniowego), jak i prawa procesowego ${ }^{10}$. Istoty konstrukcji normatywnej strony postępowania administracyjnego należy poszukiwać $\mathrm{w}$ konieczności udzielenia gwarancji procesowych podmiotom, które znajdą się w zasięgu oddziaływania skutków prawnych wydanego $\mathrm{w}$ danym postępowaniu

5 Por. A. Wróbel, w: M. Jaśkowska, A. Wróbel, Kodeks postępowania administracyjnego. Komentarz, Warszawa 2005, s. 244.

6 Por. E. Klat-Górska, L. Klat-Wertelecka, Oznaczenie strony $w$ decyzji administracyjnej, „Samorząd Terytorialny' 2004, nr 7-8, s. 44.

7 E. Iserzon, w: E. Iserzon, J. Starościak, Kodeks postępowania administracyjnego. Komentarz, teksty, wzory i formularze, Warszawa 1970, s. 93.

8 H. Knysiak-Molczyk, Uprawnienia strony $w$ postępowaniu administracyjnym, Warszawa 2004, s. 17.

9 Por. A. Wróbel, op. cit., s. 250; J. Jendrośka, Polskie postępowanie administracyjne, Kolonia Limited 2001, s. 52.

10 J. Borkowski, w: B. Adamiak, J. Borkowski, Kodeks postępowania administracyjnego. Komentar\%, Warszawa 2012, s. 190. 
administracyjnym aktu prawnego. Znajduje to odzwierciedlenie w kodeksowej definicji strony postępowania, zgodnie z którą stroną tą jest każdy, czyjego interesu prawnego lub obowiązku dotyczy postępowanie albo kto żąda czynności organu ze względu na swój interes prawny lub obowiązek (art. 28 k.p.a.).

W doktrynie prawa administracyjnego wskazuje się, iż przepis art. 28 k.p.a. zawiera dwie odrębne normy prawne: 1) „stroną jest każdy, czyjego interesu prawnego lub obowiązku dotyczy postępowanie”; 2) „stroną jest każdy [...], kto żąda czynności organu ze względu na swój interes prawny lub obowiązek"11. Rozróżnienie to stanowi podstawę dla formułowania poglądów o występowaniu dwóch procesowych ujęć strony: ujęcia „czynnego” i ujęcia „biernego”12. Stroną w ujęciu czynnym jest podmiot, który chce lub chce i powinien znaleźć się w nowej sytuacji prawnej, która da się ustalić jako wiążąca konsekwencja normy prawnej stosowanej przez organ administracji publicznej, w związku z czym podmiot ten żąda rozstrzygnięcia swojej sprawy administracyjnej przez organ ${ }^{13}$. W sytuacji tej postępowanie dotyczy bezpośrednio jego interesu prawnego lub obowiązku, w tym znaczeniu, że decyzja rozstrzyga o jego prawach lub obowiązkach. Stroną w ujęciu biernym jest natomiast osoba, której interesu prawnego lub obowiązku dotyczy postępowanie, pomimo iż ona sama postępowania tego nie inicjowała. Sytuacja taka będzie miała miejsce zarówno w przypad$\mathrm{ku}$, gdy postępowanie dotyczy interesu prawnego konkretnego podmiotu, w tym sensie, że wydana decyzja będzie rozstrzygała wprost o jego prawach lub obowiązkach (postępowanie wszczęte $\mathrm{z}$ urzędu), jak i w przypadku, gdy na prawa lub obowiązki tego podmiotu wpływa rozstrzygnięcie o prawach lub obowiązkach innej osoby (postępowanie wszczęte na wniosek innej strony). W drugim przypadku decyzja nie rozstrzyga wprost o prawach i obowiązkach tego podmiotu, lecz jedynie oddziaływa na

11 Ibidem, s. 186-187.

12 Por. W. Dawidowicz, Postepowanie administracyjne. Zarys wykładu, Warszawa 1983, s. 71; Z. R. Kmiecik, Interes prawny stron $w$ postępowaniu administracyjnym, „Państwo i Prawo” 2013, nr 1, s. 19-20.

13 W. Dawidowicz, op. cit., s. 71. 
jego prawa i obowiązki wskutek powiązania sytuacji prawnej adresata decyzji z tym podmiotem, a tym samym postępowanie dotyczy jego interesu prawnego lub obowiązku w sposób pośredni ${ }^{14}$, co wystarcza dla przypisania temu podmiotowi przymiotu strony postępowania ${ }^{15}$. W związku z powyższym należy przyjąć, iż stroną postępowania będzie zarówno podmiot lub podmioty, które wnioskują o wszczęcie postępowania w swojej sprawie, podmiot lub podmioty, w stosunku do których organ administracyjny uruchamia postępowanie z urzędu, „jak również podmiot lub podmioty, których interesom prawnym należy zapewnić ochronę $\mathrm{w}$ postępowaniu uruchomionym przez inny podmiot"16. Koncepcja biernego lub czynnego ujęcia strony postępowania administracyjnego odnosi się wyłącznie do ustalenia statusu prawnego danego podmiotu jako strony w postępowaniu administracyjnym. W żadnej mierze nie określa ona jednak wewnętrznego zróżnicowania ról procesowych w obrębie grupy podmiotów legitymujących się statusem strony w danym postępowaniu. Na gruncie przepisów kodeksu postępowania administracyjnego przyjęta została jednolita pozycja wszystkich stron postępowania $^{17}$. Jak słusznie zauważa J. Borkowski, „każda ze stron postępowania ma ten sam zakres praw i obowiązków procesowych i tak samo organ prowadzący postępowanie ma także ten sam zakres uprawnień i obowiązków procesowych wobec każdej ze stron, a wręcz - nie może go różnicować, bo prowadziłoby to do wadliwości postępowania wynikającej z naruszenia zasady równości stron"18. Przyjęcie zasady równości stron w postępowaniu administracyjnym nie wyklucza możliwości jej

14 A. Wróbel, op. cit., s. 259.

15 Por. A. Matan, Ochrona praw refleksowych $w$ postępowaniu ogólnym administracyjnym, w: Pozycja samorządowych kolegiów odwoławczych w postępowaniu administracyjnym, pod red. Cz. Martysz, A. Matan, Warszawa 2005, s. 271 i nast.

16 Por. A. Skóra, Wspótuczestnictwo $w$ postępowaniu administracyjnym, Warszawa 2009, s. 68.

17 A. Wróbel, op. cit., s. 251; Z. Kmieciak, Idea sprawiedliwości proceduralnej $w$ prawie administracyjnym (Założenia teoretyczne i doświadczenia praktyki), „Państwo i Prawo” 1994, nr 10, s. 60.

18 J. Borkowski, op. cit., s. 190. 
przełamywania poprzez wprowadzenie, w drodze normy prawa powszechnie obowiązującego, wyjątku określającego zróżnicowanie praw i obowiązków procesowych uczestników postępowania posiadających przymiot strony (np. w zakresie doręczeń). Przepisy zawierające te normy stanowić będą jednak zawsze wyjątek od zasady i jako takie podlegać będą zakazowi wykładni rozszerzającej (exceptiones non sunt extendendae) ${ }^{19}$. W doktrynie prawa administracyjnego podnoszone jest w związku z tym, iż na gruncie postępowania administracyjnego obowiązuje zasada domniemania równości uprawnień i/lub obowiązków procesowych stron, a każdy z podmiotów posiadających status strony należy do tej samej kategorii procesowej, w obrębie której, co do zasady, nie występuje zróżnicowanie ról procesowych $^{20}$. W związku z powyższym, jeżeli z przepisu prawa expressis verbis nie wynika odstępstwo od zasady równości stron $\mathrm{w}$ postępowaniu administracyjnym, nie można, pojawiających się w tym zakresie, wątpliwości procesowych interpretować na niekorzyść jakiejkolwiek ze stron ${ }^{21}$.

III.

Zastosowanie w art. 28 k.p.a. jako elementu konstrukcyjnego pojęcia strony, kryterium interesu prawnego lub obowiązku ocenianego na podstawie obowiązujących przepisów prawa powoduje nadanie pojęciu strony szerokiego wymiaru prawnego oraz sprawia, iż pojęcie to jest bardzo pojemne. Stan ten, w określonych kategoriach spraw administracyjnych, może powodować istotne trudności w ścisłym określeniu kręgu podmiotów, którym w danym postępowaniu administracyjnym przysługuje przymiot strony. $\mathrm{W}$ aktualnym stanie prawnym dostrzegalna jest $\mathrm{w}$ związku z tym preferencja ustawodawcy do wyznaczania, za pomocą odrębnej normy prawnej, katalogu podmiotów, którym w danej kategorii spraw administracyjnych

19 Por. L. Morawski, Zasady wykładni prawa, Toruń 2006, s. 171 i nast.

20 Por. A. Skóra, op. cit., s. 118.

21 Ibidem, s. 118-119. 
przyznawany jest przymiot strony ${ }^{22}$. Przyjęcie powyższego rozwiązania w znaczny sposób systematyzuje krąg uczestników danego postępowania posiadających status strony, minimalizując w ten sposób wątpliwości interpretacyjne, z drugiej stanowi jednak ograniczenie kręgu podmiotów, którym gwarantowana jest ochrona procesowa przysługujących im praw wyrażanych w formule interesu prawnego. Dlatego też zarówno w doktrynie prawa administracyjnego, jak i w orzecznictwie sądowym podnoszony jest wyjątkowy charakter tego typu przepisów, wykluczający dopuszczalność stosowania wykładni rozszerzającej ${ }^{23}$. Zasadniczym skutkiem zastosowania przez ustawodawcę analizowanej konstrukcji normatywnej jest wyznaczenie, bezpośrednio w przepisie prawa, kategorii podmiotów, którym przysługuje status strony postępowania, $\mathrm{z}$ jednoczesnym wykluczeniem możliwości uzyskania takiego statusu przez inne podmioty, niezależnie od posiadanego interesu prawnego.

Do kategorii takich właśnie przepisów należy zaliczyć art. 127 ust. 7 u.p.w., zgodnie z którym stroną postępowania w sprawie o wydanie pozwolenia wodnoprawnego jest: 1) wnioskodawca ubiegający się o wydanie pozwolenia wodnoprawnego; 2) właściciel wody, 3) właściciel urządzeń kanalizacyjnych, do których wprowadzane będą ścieki przemysłowe zawierające substancje szczególnie szkodliwe dla środowiska wodnego; 4) właściciel istniejącego urządzenia wodnego znajdującego się

22 Por. art. 28 ust. 2, art. 40 ust. 3, art. 59 ust. 8 ustawy z dnia 7 lipca 1994 r. Prawo budowlane, tekst jedn. Dz.U. z 2013 r., poz. 1409 ze zm., art. 36 ust. 4, art. 41, art. 80 ust. 3, art. 143 ustawy z dnia 9 czerwca 2011 r. Prawo geologiczne i górnicze, tekst jedn. Dz.U. z 2015 r., poz. 196 ze zm., art. 185 ustawy z dnia 27 kwietnia 2001 r. Prawo ochrony środowiska, tekst jedn. Dz.U. z 2013 r., poz. 1232 ze zm., art. 7 ust. 3a ustawy z dnia 3 lutego 1995 r. o ochronie gruntów rolnych i leśnych, tekst jedn. Dz.U. z 2015, poz. 909 ze zm., art. 118c ust. 4 ustawy z dnia 16 lipca 2004 r. Prawo telekomunikacyjne, tekst jedn. Dz.U. z 2014, poz. 243, ze zm., art. 118a ustawy z dnia 16 kwietnia 2004 r. o ochronie przyrody, tekst jedn. Dz.U. z 2015 r., poz. 1651.

23 Wyrok WSA w Gdańsku z dnia 19 listopada 2014 r., II SA/Gd 404/14, CBOSA, Wyrok WSA w Poznaniu z dnia 29 maja 2013 r., sygn. akt II SA/Po 323/13, CBOSA, wyrok WSA w Krakowie z dnia 28 stycznia 2014 r., sygn. akt II SA/Kr 1408/13, CBOSA. 
w zasięgu oddziaływania zamierzonego korzystania z wód lub planowanych do wykonania urządzeń wodnych; 5) władający powierzchnią ziemi położoną w zasięgu oddziaływania zamierzonego korzystania $\mathrm{z}$ wód lub planowanych do wykonania urządzeń wodnych; 6) uprawniony do rybactwa w zasięgu oddziaływania zamierzonego korzystania z wód lub planowanych do wykonania urządzeń wodnych. Wskazany przepis określa zamknięty katalog stron postępowania o wydanie pozwolenia wodnoprawnego. Stanowi on przepis szczególny w stosunku do art. 28 k.p.a. i tym samym wyłącza możliwość stosowania zawartych w art. 28 k.p.a. norm kodeksowych w sprawach dotyczących wydania pozwolenia wodnoprawnego. Ratio legis przyjętego na gruncie ustawy Prawo wodne rozwiązania należy upatrywać w potrzebie jednoznacznego ustalenia kategorii podmiotów, których interesy objęte zostaną ochroną procesową w związku z udzieleniem pozwolenia wodnoprawnego, ze względu na wysoką sporność tych spraw oraz rozległy zakres skutków działalności objętej pozwoleniem. Analizowany przepis prawa należy odczytywać jako potwierdzający istnienie po stronie wskazanych w nim podmiotów interesu prawnego oraz wykluczający udział w postępowaniu innych podmiotów, niezależnie od posiadanego przez nich interesu prawnego. Poza wszelkimi wątpliwościami należy przyjąć, iż wskazanym w art. 127 ust. 7 u.p.w. podmiotom ustawodawca expressis verbis przyznał przymiot strony $\mathrm{w}$ postępowaniu $\mathrm{w}$ sprawie wydania pozwolenia wodnoprawnego, przesądzając, że to ich interesu prawnego postępowanie będzie dotyczyć. Zawarta w art. 127 ust. 7 u.p.w. norma abstrakcyjna i generalna wymaga każdorazowej konkretyzacji i indywidualizacji w procesie jej stosowania. Należy w związku z tym przyjąć, iż organ administracji publicznej, prowadzący postępowanie administracyjne w sprawie pozwolenia wodnoprawnego, zobowiązany jest na jej podstawie do wyznaczenia indywidualnie oznaczonego kręgu stron danego postępowania. Wyłącznie w tak zindywidualizowanym postępowaniu możliwe jest urzeczywistnienie gwarancji procesowych przyznanych stronie, w związku z ochroną jej interesu prawnego. Jednocześnie należy podkreślić, iż wyznaczony na podstawie art. 127 ust. 7 u.p.w. krąg stron postępowania jest 
kategorią jednolitą, niepodlegającą wewnętrznemu zróżnicowaniu, co do posiadanych uprawnień w toku postępowania, chyba że przepis szczególny zróżnicowanie takie wprowadza. W każdym przypadku jednak zróżnicowanie to stanowi wyjątek od zasady równości stron $\mathrm{w}$ postępowaniu administracyjnym, w związku z czym przepis je wprowadzający podlegać musi ścisłej wykładni.

Na gruncie analizowanej sprawy przepisem wprowadzającym zróżnicowanie pozycji procesowej stron postępowania o wydanie pozwolenia wodnoprawnego jest art. 127 ust. 7a u.p.w. Zgodnie z tym przepisem, jeżeli liczba stron postępowania w sprawie o wydanie pozwolenia wodnoprawnego przekracza 20, do stron innych niż: wnioskodawca, właściciel wody, właściciel urządzeń wodnych, uprawniony do rybactwa stosuje się przepis art. 49 k.p.a. Przepis ten (art. 49 k.p.a.), zawarty w rozdziale 8 działu I k.p.a, zatytułowanym „doręczenia”, reguluje instytucję procesową określaną „doręczeniem przez obwieszczenie"24. Dopuszczalność zastosowania, w toku postępowania administracyjnego, doręczeń pism procesowych poprzez ich obwieszczenie została ograniczona wyłącznie do sytuacji wskazanych wprost w przepisach szczególnych. Oznacza to, iż art. 49 k.p.a. nie może stanowić samodzielnej podstawy dokonywania doręczeń przez obwieszczenie, gdyż do zastosowania zawartej w nim normy prawnej konieczne jest upoważnienie wynikające z przepisu szczególnego. Takim przepisem szczególnym jest właśnie art. 127 ust. 7a u.p.w., który upoważnia do dokonywania przez organy administracji publicznej, $\mathrm{w}$ toku postępowania o wydanie pozwolenia wodnoprawnego, doręczeń wskazanym w nim stronom postępowania w trybie art. 49 k.p.a. Należy w związku z tym przyjąć, iż art. 127 ust. 7a u.p.w., wraz z przepisami kodeksowymi, reguluje instytucję doręczeń w postępowaniu o wydanie pozwolenia wodnoprawnego i taki, i tylko taki, jest przedmiot wprowadzonych tym przepisem odmienności, a co się z tym wiąże zróżnicowań pozycji stron w tym postępowaniu. Przepis ten, z całą pewnością, nie stanowi

24 G. Łaszczyca, w: G. Łaszczyca, Cz. Martysz, A. Matan, Postępowanie administracyjne ogólne, Warszawa 2003, s. 436. 
i nie może stanowić normy wyznaczającej krąg stron postępowania $^{25}$, jak również normy różnicującej pozycję stron tego postępowania, w zakresie innym niż doręczenia.

W doktrynie prawa administracyjnego wskazuje się, iż doręczenie - mimo iż wywołuje szereg skutków prawnych - nie jest czynnością prawną, lecz ma charakter czynności materialno-technicznej ${ }^{26}$. Celem bezpośrednim tej czynności nie jest wywołanie skutków prawnych poprzez ustanowienie normy porządku prawnego, lecz spowodowanie zmian w sferze faktycznej, tj. dostarczenie pisma jego adresatowi w celu powiadomienia go o treści pisma ${ }^{27}$. Skutki prawne doręczenia nie powstają przez ustanowienie nowej normy porządku prawnego, lecz w drodze faktów, z którymi obowiązujące przepisy prawa wiążą określone konsekwencje w sferze stosunków prawnych ${ }^{28}$. Ze względu na doniosłość skutków prawnych doręczeń w postępowaniu administracyjnym czynności te charakteryzują się wysokim stopniem sformalizowania, z jednoczesnym podporządkowaniem ich zasadzie oficjalności. W kontekście tych właśnie cech należy upatrywać celów dopuszczenia, na zasadach wyjątku, doręczeń przez obwieszczenie. W mojej ocenie celem regulacji zawartej w art. 49 k.p.a. jest przede wszystkim uproszczenie procedury doręczenia oraz obniżenie kosztów administrowania poprzez zwolnienie organu z obowiązku ustalenia adresów stron, sporządzania dokumentów w dużej liczbie egzemplarzy, dokonywania wysyłki pism oraz oczekiwania na zwrotne potwierdzenie jej odbioru, a także ujednolicenie momentu skutecznego doręczenia pisma w drodze obwieszczenia. Dlatego też nie sposób, moim zdaniem, zaakceptować stanowi-

25 Por. wyrok NSA z dnia 1 lutego 2011, II OSK 241/10, CBOSA, w którym sąd przyjął, że przepis art. 127 ust. 9 (obecnie art. 127 ust. 7a) ustawy Prawo wodne jest to unormowanie lex specialis wobec art. 49 k.p.a. w zakresie dotyczącym ustalenia stron postępowania w tego rodzaju sprawach. Podobnie WSA w Krakowie w wyroku z dnia 12 marca 2012 r., II SA/Kr 1739/11.

26 J. Borkowski, op. cit., s. 241.

27 M. Masternak, Doręczenia w postępowaniu podatkowym, w: Wykładnia i stosowanie prawa podatkowego. Węzłowe problemy, red. B. Brzeziński, Warszawa 2013, s. 55.

28 Ibidem, s. 55. 
ska sądu, że „gdyby organ musiał ustalać krąg stron postępowania, to nie byłoby potrzeby wprowadzania szczególnego trybu informowania stron o decyzjach i innych czynnościach postępowania".

Analiza treści art. 127 ust. 7a u.p.w. wskazuje, iż warunkiem sine qua non dokonywania doręczeń przez obwieszczenie, wskazanym $\mathrm{w}$ tym przepisie stronom postępowania o wydanie pozwolenia wodnoprawnego, jest ustalenie, iż w postępowaniu tym liczba stron przekracza 20. Ustalenie to może zostać dokonane wyłącznie wówczas, gdy organ na etapie wszczęcia postępowania określi krąg jego stron na podstawie art. 127 ust. 7 u.p.w. Dlatego też słusznie, w wyroku z dnia 1 lutego 2011 r., NSA stwierdził, że „doręczenie bądź zawiadomienie $\mathrm{w}$ drodze obwieszczenia publicznego o którym stanowi art. 49 k.p.a. nie może być stosowane, jeżeli z góry nie można ustalić kręgu podmiotów, które powinny wziąć udział w całym postępowaniu lub w niektórych jego czynnościach. Stąd, właściwy organ musi w tej sprawie w pierwszej kolejności ustalić krąg stron postępowania żeby ustalić czy ich liczba przekracza 20, ponieważ determinuje to dalszy przebieg postępowania administracyjnego" 29 . Ustalenie kręgu stron postępowania determinuje samą możliwość zastosowania art. 49 k.p.a., jak również wyznacza adresatów podjętej czynności. Zgodnie z art. 49 k.p.a., $\mathrm{w}$ trybie tego przepisu, o decyzjach i innych czynnościach organów administracji publicznej mogą być zawiadamiane strony, co oznacza, iż posiadanie przymiotu strony jest uprzednie w stosunku do skutecznie podjętej czynności zawiadomienia. Prowadzi to do wniosku, iż przed podjęciem czynności doręczenia organ powinien wiedzieć względem kogo czynność ta jest podejmowana.

Jednocześnie należy podkreślić, iż ścisłe ustalenie przez organ kręgu stron postępowania nie wynika z konieczności ustalenia listy adresatów pism procesowych, lecz z istoty postępowania administracyjnego. Jak słusznie zauważa Z. Kmieciak, fundamentalnym założeniem i celem postępowania administracyjnego typu jurysdykcyjnego jest zapewnienie ochrony, mają-

29 Wyrok NSA z dnia 1 lutego 2011 r., II OSK 241/10, CBOSA. 
cemu charakter kwalifikowany, interesowi indywidualnemu ${ }^{30}$. „Poszczególne instytucje postępowania administracyjnego nakierowane są przede wszystkim, jeśli nawet nie wyłącznie, na ochronę tego interesu. Mają one chronić jednostkę i jej interesy w postępowaniu przed organami administracyjnymi, reprezentującymi interes publiczny, społeczny"31. Przy tak określonych założeniach i celach postępowania administracyjnego instytucja doręczeń pełni funkcję służebną, służy realizacji przyjętych zasad postępowania, pozostając jednak wyłącznie czynnością faktyczną podejmowaną $\mathrm{w}$ toku tegoż postępowania. Ma ona charakter posiłkowy, uzupełniający wobec czynności prawnych podejmowanych przez organ prowadzący postępowanie, zdeterminowanych przedmiotem postępowania administracyjnego, którym jest indywidualna sprawa administracyjna. Wymiarem indywidualności tej sprawy jest ścisłe ustalenie kręgu podmiotów określanych mianem stron postępowania, których sytuację prawną ukształtują skutki prawne podjętych przez organ czynności.

Przepis art. 127 ust. 7a u.p.w., upoważniający do stosowania w postępowaniu o wydanie pozwolenia wodnoprawnego art. 49 k.p.a., jest przepisem procesowym, który wraz z przepisami kodeksu postępowania administracyjnego reguluje instytucję doręczeń w danym rodzaju postępowań administracyjnych. Zawarta $\mathrm{w}$ tym przepisie regulacja stanowi podstawę zróżnicowania sytuacji procesowej stron postępowania o wydanie pozwolenia wodnoprawnego w zakresie trybu dokonywanych doręczeń. Przepis ten stanowi w związku z tym wyjątek od zasady równości stron postępowania administracyjnego i jako taki nie może podlegać wykładni rozszerzającej. Zarówno na poziomie wykładni językowej, jak i wykładni systemowej i celowościowej brak jest jakichkolwiek podstaw do przyjęcia, iż przepis ten

30 Z. Kmieciak, Zarys teorii postepowania administracyjnego, Warszawa 2014, s. 182.

31 T. Woś, Obowiązek uwzględnienia interesu społecznego i słusznego interesu obywateli $w$ toku postępowania administracyjnego (art. 7 in fine k.p.a.), „Krakowskie Studia Prawnicze”, Rok XX, Wrocław-Warszawa-Kraków-Gdańsk-Łódź 1987, s. 106. 
zwalnia organ prowadzący postępowanie z obowiązku ustalenia stron tegoż postępowania, a w konsekwencji również stron podejmowanej decyzji administracyjnej, poprzez ich wskazanie za pomocą cech indywidualizujących (imię, nazwisko, firma osoby prawnej).

Kontakt e-mail:

szalew@law.umk.pl 